\title{
LA RESPONSABILIDAD POR VULNERACIÓN DE DERECHOS FUNDAMENTALES Y EL RECONOCIMIENTO DEL PRINCIPIO DE SUPREMACÍA DE DICHOS DERECHOS \\ Comentario de la sentencia del Tribunal Constitucional recaída en el artículo 2331 del Código Civil
}

\section{Gonzalo Aguilar Cavallo*}

\section{INTRODUCCIÓN}

Con fecha 10 de junio de 2008, el Tribunal Constitucional de Chile se pronunció sobre la inaplicabilidad por inconstitucionalidad del artículo 2331 del Código Civil promovido por el abogado señor Luis Carlos Valdés Correa (en adelante, el caso del artículo 2331 del Código Civil). Esta sentencia es relevante por diversos motivos, entre los cuales se pueden mencionar, inter alia, el reconocimiento del principio de responsabilidad por vulneración de los derechos humanos como un principio de carácter constitucional, la reiteración del principio de sujeción de todas las reglas y normas del ordenamiento a los principios y valores constitucionales y, finalmente, la reafirmación del principio de supremacía de los derechos fundamentales como un principio rector respecto del cual se estructura la globalidad del ordenamiento jurídico. A continuación, nuestro comentario se enfocará a cada una de estas cuestiones, repasando brevemente, en primer lugar, los hechos de la causa.

\section{1) LOS HECHOS}

En el requerimiento de inaplicabilidad, el requirente solicita se declare inaplicable en la causa Rol No 2429-2007, seguida ante el Decimoctavo Juzgado Civil de Santiago, el artículo 2331 del Código Civil, por contravenir los numerales 4 y 26 del artículo 19 de la Constitución Política de la República, esto es, el derecho a la vida privada y a la honra de las per-

Profesor de Derecho Internacional Público y Derechos Humanos de la Universidad de Talca, Doctor en Derecho, MA en Relaciones Internacionales y LLM en Derechos Humanos y Derecho Humanitario. Centro de Estudios Constitucionales, Universidad de Talca (Chile). Correo electrónico: gaguilar@utalca.cl Fecha de recepción: 26 de marzo de 2009

Fecha de aprobación: 4 de junio de 2009 
sonas y la seguridad de que los preceptos legales que por mandato de la Constitución regulen o complementen las garantías que esta establece o que las limiten en los casos en que ella lo autoriza, no podrán afectar los derechos en su esencia, ni imponer condiciones, tributos o requisitos que impidan su libre ejercicio ${ }^{1}$.

En efecto, el requirente inició un juicio ordinario para obtener la indemnización de los perjuicios causados y la reparación extrapatrimonial del daño sufrido como consecuencia de la afectación grave de su honor, su intimidad y sus derechos como abogado en las relaciones con sus clientes. El requirente era socio del estudio jurídico del cual forman parte los demandados y, por problemas societarios, fue excluido de la sociedad. En este juicio, se planteaba la posibilidad de que el artículo 2331 del Código Civil resultaría finalmente aplicado, razón por la cual se dedujo el referido requerimiento. En este sentido, el Tribunal Constitucional chileno seńaló claramente que "el precepto legal impugnado tiene por objeto delimitar la tutela civil por responsabilidad en la lesión deliberada o negligente del derecho a la honra de otro, dando lugar a indemnización únicamente por aquellos dańos que pueda probarse que produjeron un empobrecimiento patrimonial de la víctima y negándola del todo cuando este dańo material no puede probarse. Esto es, como ya se ha dicho, prohibiendo la indemnización pecuniaria del daño exclusivamente moral ocasionado por imputaciones injuriosas contra el honor o el crédito de una persona, aun cuando dicho dańo estuviere, a juicio del juez de la causa, suficientemente probado" 2 .

\section{2) EL RECONOCIMIENTO DEL PRINCIPIO DE RESPONSABILIDAD COMO UN PRINCIPIO DE CARÁCTER CONSTITUCIONAL}

La sentencia que comentamos ratifica, con rango constitucional, el que denomina principio de responsabilidad. En efecto, en la referida decisión, los jueces constitucionales seńalan que "el principio de responsabilidad así concebido no queda restringido al ámbito puramente legal, pues está incorporado al ordenamiento constitucional que no solo otorga rango constitucional a la responsabilidad civil y penal, al remitirse a ellas la Carta Suprema en numerosos casos en que las alude directamente, o lo hace respecto de ciertos delitos o de los dańos y perjuicios que causan

Tribunal Constitucional de Chile. 10 de junio de 2008. Rol No 943-2008. Requerimiento de inaplicabilidad por inconstitucionalidad presentado por Luis Carlos Valdés Correa en relación al articulo 2.331 del Código Civil, en causa Rol No 2429-2007 caratulada "Valdés con Jaime Irarrázabal Covarrubias y otros", del Decimoctavo Juzgado Civil de Santiago. Considerando $1^{\circ}$, p. 6.

2 TC. Rol No $943-2008$, considerando $29^{\circ}$, p. 28. 
determinadas autoridades o ciertas circunstancias, sino que, además, consagra estatutos de responsabilidad constitucional concretos, o encomienda expresamente al legislador hacerlo"3.

Además, el propio Tribunal Constitucional, con precisión a nuestro entender, afirma que la obligación de responder por los perjuicios causados por la infracción de un deber jurídico es un principio que impregna, atraviesa, inspira e informa todo nuestro ordenamiento jurídico -lo cual se encuentra especialmente reforzado en el seno de una sociedad democrática y social de derecho- y que adquiere variadas formas a través de estatutos jurídicos especiales de responsabilidad. Así, el máximo órgano jurisdiccional constitucional, en forma muy clara, reconoce que "la obligación de responder por los perjuicios causados por la infracción de un deber jurídico, sea sufriendo el castigo por el delito cometido si se ha perjudicado a la sociedad quebrantando la ley penal, sea satisfaciendo la indemnización del dańo infligido a otro cuando deliberadamente o por pura negligencia se ha contravenido una obligación de carácter civil, configura el principio de responsabilidad, que impregna todo nuestro ordenamiento jurídico y adquiere las más variadas formas a través de estatutos jurídicos especiales de responsabilidad. Se habla, así, dependiendo del deber jurídico infringido, de responsabilidad penal, responsabilidad civil, responsabilidad política o constitucional, responsabilidad administrativa, responsabilidad medio ambiental, etcétera; pudiendo una misma infracción generar una o más clases de responsabilidad que pueden concurrir separada o conjuntamente" ${ }^{\text {. }}$.

Junto a lo anterior, el fallo mencionado se refiere, correctamente en nuestra opinión, a la responsabilidad del Estado por los perjuicios causados tanto por su actividad como por su inactividad. De este modo, la sentencia señala que "la Carta Fundamental contempla normas expresas que regulan la responsabilidad del propio Estado por los dańos y perjuicios que causen su actividad o, incluso, su inactividad"s.

Hasta aquí concordamos con todas las aseveraciones efectuadas por el Tribunal Constitucional en este remarcable fallo que sin lugar a dudas, constituye un punto de inicio de futuros desarrollos normativos destinados a poner al día nuestro ordenamiento, anclado todavía, en muchos aspectos, en figuras y principios que en el derecho internacional y comparado han experimentado un avance progresivo.

Nuestra observación apunta a la afirmación efectuada por el Tribunal Constitucional en el sentido de señalar que "como es sabido, la responsabilidad civil como deber de indemnizar el dańo inferido a otro

TC. Rol No $943-2008$, considerando $13^{\circ}$, p. 14 .

TC. Rol No 943-2008, considerando $12^{\circ}$, p. 13.

TC. Rol No 943-2008, considerando $15^{\circ}$, p. 16. 
es también procedente tratándose de la lesión de un derecho constitucional", entendiendo por estos los derechos fundamentales, tales como el derecho a la vida, el derecho a la integridad física y psíquica, el derecho a la vida privada y al honor de las personas, el derecho a la libertad de expresión e información, etc. ${ }^{6}$. Sin embargo, de entrada, se puede apreciar que la vulneración de los derechos fundamentales presenta un régimen de responsabilidad especial, dotado de específicas características, distintas y que divergen, en muchos aspectos, del régimen de responsabilidad civil.

En efecto, el Derecho de los derechos humanos ha desarrollado, desde hace muchos ańos, un régimen de responsabilidad especial y diferenciado, dotado de especificidades propias, cuya fuente se puede encontrar -a través de un rico desarrollo normativo y doctrinario- tanto en el Derecho Internacional convencional de los derechos humanos como en el Derecho Internacional consuetudinario de los derechos humanos, pero también en el Derecho Internacional penal, en el Derecho Internacional Humanitario y en el Derecho Internacional del Medio Ambiente. Además, debe tenerse particularmente presente, desde el punto de vista de las fuentes y de la especificidad concreta de este régimen especial de responsabilidad derivado de la vulneración a los derechos humanos, la aplicación y las enseñanzas emanadas de los tribunales tanto nacionales, extranjeros e internacionales que se han pronunciado sobre la responsabilidad en casos de atentados o violaciones a los derechos humanos, tales como la Corte Interamericana de Derechos Humanos. A mayor abundamiento, y con el objeto de reforzar la idea de la existencia de un régimen especial de responsabilidad en casos de violaciones a los derechos fundamentales, resulta imprescindible hacer referencia a los diversos pronunciamientos efectuados por la Corte Suprema de Chile, tales como el caso Jorquera Gutiérrez, el caso Liquiñe, o el caso Lazo $\mathrm{Lazo}^{7}$, en donde se ha reconocido la existencia de este régimen especial de responsabilidad, con apoyo en las enseńanzas y estándares provenientes del Derecho Internacional, y donde se ha realizado una clara distinción entre el régimen de responsabilidad por violaciones a los derechos humanos y el régimen de responsabilidad civil regulada por el Código Civil.

Por ejemplo, en el caso Lazo Lazo, la Corte Suprema claramente afirmó que "de esta manera, al confirmar la decisión que rechaza la acción civil por estimarla prescrita, los sentenciadores del grado han incurrido en error de derecho al no dar aplicación a los tratados internacionales sus-

TC. Rol No 943-2008, considerando $15^{\circ}$, p. 16.

Corte Suprema. 16 de septiembre de 2008. Rol No 5789-07, Secuestro Calificado de Guillermo Jorquera Gutiérrez; Corte Suprema. 25 de septiembre de 2008. Rol No 4662-07, Caso Episodio Liquiñe; Corte Suprema. 29 de octubre de 2008. Rol 6212-07, Caso de secuestro calificado de Ofelia Lazo Lazo. 
critos por nuestro país, ni interpretar debidamente las normas de derecho internacional consideradas ius cogens por la comunidad jurídica internacional, disposiciones que deben tener aplicación preferente en nuestro ordenamiento interno al tenor de lo que dispone el artículo $5^{\circ}$ de la Constitución Política de la República, por sobre aquellas disposiciones de orden jurídico nacional que posibilitarían eludir las responsabilidades en que ha incurrido el Estado de Chile, a través de la actuación penalmente culpable de sus funcionarios, dando cumplimiento de este modo a los artículos 27 y 53 de la Convención de Viena sobre el Derecho de los Tratados, yerro jurídico que habilita a este tribunal para invalidar la sentencia que se revisa y dictar la de reemplazo correspondiente" 8 .

Dos antecedentes sirven para profundizar este razonamiento. En primer lugar, el Código Civil y sus normas de responsabilidad civil no fueron pensadas para enfrentar la coyuntura de violaciones a los derechos humanos. En consecuencia, dichas normas y la estructura de dicho régimen civil no es adecuada ni procedente para resolver la exigencia de reparación en casos de violaciones a los derechos humanos. Indudablemente, no es lo mismo el incumplimiento de un contrato de compraventa que la vulneración del derecho a la integridad física, del derecho a la igualdad y prohibición de la discriminación, del derecho a la vida privada, del derecho al acceso a la justicia, y mucho menos aun que la violación del derecho a la educación, del derecho a la seguridad social, del derecho a la salud o del derecho a vivir en un medio ambiente libre de contaminación.

En segundo lugar, por qué insistir en el régimen de responsabilidad de acuerdo al Código Civil, si efectivamente, existe un régimen de responsabilidad particular para violaciones a los derechos fundamentales, que sí estaría dotado de una estructura adecuada para procurar la reparación integral del daño. En este orden de cosas, qué sentido tiene aludir a expresiones como "la lesión a un interés del demandante", a la "doctrina civil francesa" o a "ventajas o beneficios patrimoniales o extrapatrimoniales", cuando estamos en presencia de un derecho fundamental vulnerado, con las peculiaridades innegables que estos derechos, y las consecuencias de su violación, tienen?

A nuestro modo de ver, nuestro ordenamiento interno y los operadores que en él intervienen deben abrirse a la existencia de estos regímenes de responsabilidad particulares provenientes, en este caso, del Derecho Internacional de los derechos humanos. A continuación examinaremos brevemente, la existencia de este estatuto jurídico específico de responsabilidad, comenzando por un esbozo genérico de la responsabilidad en Derecho Internacional y, luego de la responsabilidad, que se ha ido acotando 
en Derecho Internacional, cuando se trata de violaciones a los derechos fundamentales.

\section{(2.1) RESPONSABILIDAD ESPECÍFICA DEL DERECHO INTERNACIONAL}

La rápida revisión que aquí se hace de la responsabilidad en Derecho Internacional tiene por objeto demostrar la existencia de un núcleo normativo consolidado de responsabilidad en Derecho Internacional con especificidades propias.

En el Derecho Internacional, desde muy antiguo, la Corte Permanente de Justicia Internacional, primero, y la Corte Internacional de Justicia, después, han reiterado la existencia y absoluta vigencia de este principio de responsabilidad, que se traduce, como consecuencia, en una obligación, cual es la de reparar adecuada e integralmente el perjuicio causado, id est, todo daño causado por el hecho ilícito, y en lo que nos interesa, este hecho ilícito estaría constituido por la violación de un derecho humano ${ }^{10}$. La obligación de reparación integral consiste en "hacer desaparecer todas las consecuencias del hecho ilícito y restablecer la situación que, con toda probabilidad, habría existido de no haberse cometido el hecho"11.

Desde el punto de vista internacional, esta materia ha sido parcialmente regulada en el proyecto de artículos sobre responsabilidad internacional de los Estados aprobado por la Comisión de Derecho Internacional (en adelante, la CDI) y anexado en una resolución de la Asamblea Gene-

Corte Permanente de Justicia Internacional. Caso Fábrica de Chorzów. Series A, No. 17, p. 47; Corte Internacional de Justicia. "Actividades militares y paramilitares en Nicaragua y contra Nicaragua (Nicaragua c. Estados Unidos de América)". I.C.J. Reports 1986, p. 64, par. 115; Corte Internacional de Justicia. "Caso relativo al Proyecto Gabč́́kovo-Nagymaros (Hungría/Eslovaquia)". I.C.J. Reports 1997, p. 81, par. 152; Opinión Consultiva de la Corte Internacional de Justicia. "Consecuencias jurídicas de la construcción de un muro en el territorio palestino ocupado". I.C.J. Reports 2004, p. 198, pars. 152 y 153; y Corte Internacional de Justicia. 26 de febrero de 2007. Application of the Convention on the Prevention and Punishment of the Crime of Genocide (Bosnia and Herzegovina v. Serbia and Montenegro). Desde el punto de vista de la responsabilidad penal, TPIY. 15 de julio de 1999. IT-94-1-A, Caso Tadić; desde la perspectiva de la justicia internacional arbitral, Tribunal Constituted in Accordance with Article 19 of the Treaty between the French Republic and the United Kingdom of Great Britain and Northern Ireland Concerning the Construction and Operation by Private Concessionaries of a Channel Fixed Link Signed at Canterbury on 12 February 1986. 30 de enero de 2007. Laudo parcial, In the Matter of an Arbitration, The Channel Tunnel Group Limited, France-Manche S.A. and The Secretary of State for Transport of the Government of the United Kingdom of Great Britain and Northern Ireland, Le Ministre de l'équipement, des transports, de l'aménagement du territoire, du tourisme et de la mer du Gouvernement de la République Française.

11 Asamblea General Naciones Unidas. Documentos Oficiales. $56^{\circ}$ período de sesiones. Suplemento No $10(\mathrm{~A} / 56 / 10)$. Informe de la Comisión de Derecho Internacional. $53^{\text {er }}$ período de sesiones (23 de abril a 1 de junio y 2 de julio a 10 de agosto de 2001), Nueva York, 2001, p. 236; Vid. Factory at Chorzów, Merits, 1928, P.C.I.J., Series A, No 17, p. 47. 
$\mathrm{ral}^{12}$. Este Proyecto de artículos solo regula parcialmente el derecho de la responsabilidad ya que solo se refiere a la responsabilidad del Estado, por un lado, y se concentra en la responsabilidad por acto ilícito, por otro.

En efecto, la Comisión de Derecho Internacional prefirió separar el estudio de la cuestión, y ha examinado el tema de la "Responsabilidad internacional por las consecuencias perjudiciales de actos no prohibidos por el derecho internacional" (Responsabilidad Internacional en caso de Pérdida Causada por un Daño Transfronterizo Resultante de Actividades Peligrosas) ${ }^{13}$. Del mismo modo, la CDI actualmente se encuentra trabajando sobre la responsabilidad internacional de las organizaciones inter-

Asamblea General de las Naciones Unidas. Proyecto de Articulos sobre Responsabilidad del Estado por Hechos Internacionalmente Ilícitos, adoptado por la Comisión de Derecho Internacional en su $53^{\text {er }}$ período de sesiones (A/56/10) y anexado a la Resolución 56/83, de 12 de diciembre de 2001.

13 La Comisión de Derecho Internacional, en su $30^{\circ}$ período de sesiones (1978), incluyó el tema "Responsabilidad internacional por las consecuencias perjudiciales de actos no prohibidos por el derecho internacional" (Responsabilidad Internacional en caso de Pérdida Causada por un Daño Transfronterizo Resultante de Actividades Peligrosas) en su programa de trabajo y nombró Relator Especial al Sr. Robert Q. Quentin-Baxter. En su 2910ª sesión, celebrada el 8 de agosto de 2006, la Comisión recordó que en su $49^{\circ}$ período de sesiones (1997) había decidido examinar el tema en dos partes y que, en su $53^{\text {er }}$ período de sesiones (2001), había concluido el examen de la primera parte sobre Proyectos de articulo sobre la prevención del daño transfronterizo resultante de actividades peligrosas, había aprobado el texto definitivo de un proyecto de preámbulo y un total de 19 proyectos de artículo sobre la prevención del dańo transfronterizo resultante de actividades peligrosas y había recomendado a la Asamblea General la elaboración de una convención basada en el proyecto de artículos antes mencionado. La recomendación de la Comisión descansaba en la idea de que, teniendo presente la práctica actualmente seguida por los Estados, la primera parte del tema se prestaba a la codificación el desarrollo progresivo por medio de una convención. AsAmbleA General Naciones Unidas. Documentos Oficiales. Texto del Proyectos de articulos sobre la prevención del daño transfronterizo resultante de actividades peligrosas, $56^{\circ}$ Período de sesiones. Suplemento No $10(\mathrm{~A} / 56 / 10)$. Informe de la Comisión de Derecho Internacional. $53^{\text {er }}$ período de sesiones ( 23 de abril a 1 de junio y 2 de julio a 10 de agosto de 2001), Nueva York, 2001, pp. 406-485. Por su parte, en su 2882a sesión, el 2 de junio de 2006, la Comisión recibió y examinó el informe del Comité de Redacción (A/CN.4/L.686) y aprobó en segunda lectura el texto del preámbulo y un total de ocho proyectos de principio sobre la asignación de la pérdida en caso de dańo transfronterizo resultante de actividades peligrosas. La aprobación por la Comisión del Proyecto de principios sobre la asignación de la pérdida en caso de daño transfronterizo resultante de actividades peligrosas completa la segunda parte, con lo que concluyen los trabajos sobre el tema "Responsabilidad internacional por las consecuencias perjudiciales de actos no prohibidos por el derecho internacional". De conformidad con el artículo 23 de su Estatuto, la Comisión recomienda, con respecto a esta segunda parte, que la Asamblea General haga suyo el proyecto de principios mediante una resolución e inste a los Estados a que adopten disposiciones en el ámbito interno y en el internacional para llevarlos a efecto. Asamblea General Naciones Unidas. Proyecto de principios sobre la asignación de la pérdida en caso de daño transfronterizo resultante de actividades peligrosas, Informe de la Comisión de Derecho Internacional correspondiente al $58^{\circ}$ Período de sesiones ( 1 de mayo a 9 de junio y 3 de julio a 11 de agosto de 2006), en el marco del Proyecto sobre Responsabilidad de las Organizaciones Internacionales A/61/10. Documentos Oficiales, $61^{\mathrm{er}}$ período de sesiones, Suplemento No 10 (A/61/10), pp. 115-205. 
nacionales ${ }^{14}$. Además, es posible señalar que existen, también, regímenes especiales de responsabilidad internacional del Estado, por ejemplo, en materia medio ambiental ${ }^{15}$.

Con todo, uno de los avances más relevantes del Proyecto de Artículos sobre Responsabilidad del Estado por hechos internacionalmente ilicitos es la incorporación de una responsabilidad más intensa, esto es, de una responsabilidad agravada en casos de violaciones de una obligación internacional fundamental para la existencia de la comunidad internacional en su conjunto $^{16}$. En el fondo, el Proyecto de responsabilidad se está refiriendo en este caso a la violación de las obligaciones que derivan de una norma de ius cogens o imperativas de Derecho Internacional general. En este sentido, el Proyecto de responsabilidad establece un número de consecuencias adicionales respecto del Estado infractor y respecto de los otros Estados.

14 En su $52^{\circ}$ período de sesiones, celebrado en 2000, la Comisión decidió incluir el tema "Responsabilidad de las organizaciones internacionales" en su programa de trabajo a largo plazo. Asamblea General Naciones Unidas. Documentos Oficiales, quincuagésimo quinto período de sesiones, Suplemento $N^{\circ} 10$ (A/55/10), par. 729. En su $54^{\circ}$ período de sesiones, la Comisión decidió, en su $2717^{\text {a }}$ sesión, celebrada el 8 de mayo de 2002 , incluir el tema en su programa de trabajo y nombró Relator Especial del tema al Sr. Giorgio Gaja. AsAmbleA General Naciones Unidas. Documentos Oficiales de la quincuagésimo séptimo período de sesiones, Suplemento No 10 (A/57/10 y Corr.1), pars. 461 a 463; Asamblea General Naciones Unidas. Documentos Oficiales. $60^{\circ}$ período de sesiones. Suplemento No 10 (A/60/10). Informe de la Comisión de Derecho Internacional. $57^{\circ}$ período de sesiones (2 de mayo a 3 de junio y 11 de julio a 5 de agosto de 2005), Nueva York, 2005, pp. 80-115. En su $58^{\circ}$ período de sesiones, la Comisión examinó el cuarto informe del Relator Especial (A) CN.4/564 y Add.1 y 2) y aprobó 14 proyectos de artículo, con sus comentarios, sobre las circunstancias que excluyen la ilicitud y sobre la responsabilidad de un Estado en relación con un hecho de una organización internacional (cap. VII). Asamblea General Naciones Unidas. Informe de la Comisión de Derecho Internacional (CDI) correspondiente al $58^{\circ}$ Período de sesiones ( 1 de mayo a 9 de junio y 3 de julio a 11 de agosto de 2006), en el marco del Proyecto sobre Responsabilidad de las Organizaciones Internacionales A/61/10. Documentos Oficiales, 61 ${ }^{\mathrm{er}}$ período de sesiones, Suplemento No 10 (A/61/10), pp. 277-327. Ortiz AHLF, Loretta (1998). "Responsabilidad internacional en materia ambiental", en VV.AA. La responsabilidad juridica en el daño ambiental, México: Instituto de Investigaciones Jurídicas, pp. 153-175.

16 "Artículo 40.- Aplicación de este capítulo: 1. El presente capítulo se aplicará a la responsabilidad internacional generada por una violación grave por el Estado de una obligación que emane de una norma imperativa de derecho internacional general. 2. La violación de tal obligación es grave si implica el incumplimiento flagrante o sistemático de la obligación por el Estado responsable.

Artículo 41.- Consecuencias particulares de la violación grave de una obligación en virtud del presente capítulo: 1. Los Estados deben cooperar para poner fin, por medios lícitos, a toda violación grave en el sentido del artículo 40. 2. Ningún Estado reconocerá como lícita una situación creada por una violación grave en el sentido del artículo 40, ni prestará ayuda o asistencia para mantener esa situación. 3. El presente artículo se entenderá sin perjuicio de las demás consecuencias enunciadas en esta parte y de toda otra consecuencia que una violación a la que se aplique el presente capítulo pueda generar según el derecho internacional". Proyecto de Articulos sobre Responsabilidad del Estado por hechos internacionalmente ilicitos, adoptado por la Comisión de Derecho Internacional en su $53^{\circ}$ período de sesiones (A/56/10) y anexado por la AG en su Resolución 56/83, de 12 de diciembre de 2001. 
En efecto, el Derecho de la Responsabilidad Internacional del Estado ha incluido las violaciones graves de obligaciones contraídas en virtud de normas imperativas de Derecho Internacional general. Esta distinción entre violaciones graves y violaciones ordinarias no hace sino reiterar la división efectuada por la Corte Internacional de Justicia en el caso de la Barcelona Traction, al referirse a las obligaciones debidas a la comunidad internacional en su conjunto y esenciales para la protección de sus intereses fundamentales ${ }^{17}$.

En los comentarios al Proyecto de Artículos sobre Responsabilidad Internacional del Estado, se señalan como ejemplos de normas imperativas de Derecho Internacional general, la prohibición de la esclavitud, la trata de esclavos, el genocidio, la discriminación racial y el apartheid, y la prohibición de la tortura y de los tratos crueles, inhumanos y degradantes ${ }^{18}$.

\section{(2.2) RESPONSABILIDAD POR VIOLACIONES A LOS DERECHOS HUMANOS}

Junto con lo anterior, en el seno de la Organización de las Naciones Unidas también se estuvo trabajando en la regulación de un cuerpo de normas referidas a la responsabilidad, pero, sobre todo, relativas a la obligación que surge como consecuencia de la violación de una obligación vinculada a las normas de derechos humanos y derecho humanitario, esto es, la obligación de reparar cuando se ha violado una norma fundamental de Derecho Internacional Humanitario o de Derecho Internacional de los derechos humanos. Nos estamos refiriendo a los Principios y directrices básicos sobre el derecho de las victimas de violaciones manifiestas de las normas internacionales de derechos humanos y de violaciones graves del derecho internacional humanitario a interponer recursos y obtener reparaciones.

Este conjunto de principios y directrices complementado con las disposiciones contenidas en el Proyecto de Articulos sobre la Responsabilidad del Estado por hechos internacionalmente ilicitos, constituyen un cuerpo de normas, principios y estándares que han generado un corpus iuris especial sobre responsabilidad en casos de violaciones de los derechos humanos.

17 CIJ. 1970. "Barcelona Traction, Light and Power Company", Limited. Second Phase, ICJ Reports, par. 33, p. 32.

18 Asamblea General. Naciones Unidas. Proyecto de Articulos sobre Responsabilidad del Estado por Hechos Internacionalmente Ilícitos, p. 303. Desde un punto de vista muy vinculado con las normas de ius cogens, según la Corte Internacional de Justicia, hay obligaciones erga omnes que "dimanan, por ejemplo, en el derecho internacional contemporáneo, de la proscripción de los actos de agresión y del genocidio, así como de los principios y normas relativos a los derechos fundamentales de la persona humana, incluida la protección contra la esclavitud y la discriminación racial". CIJ. 1970. "Barcelona Traction, Light and Power Company", par. 34, p. 32; CIJ. 1995. "East Timor (Portugal v. Australia)", ICJ Reports, par. 29, p. 102; CIJ. 1996. "Legality of the Threat or Use of Nuclear Weapons, Prevention and Punishment of the Crime of Genocide, Preliminary Objections", ICJ Reports, pars. 31-32, pp. 615-616. 
Desde el punto de vista penal, el Estatuto de Roma y un conjunto de otras disposiciones convencionales, normas internacionales consuetudinarias y principios generales del derecho, que componen el Derecho Internacional Público, rigen todo lo relativo a la responsabilidad internacional penal del individuo.

En consecuencia, aun en el orden interno de los Estados, la regulación de la responsabilidad del Estado -e incluso de particulares- en casos de violación de los derechos humanos no puede quedar entregada a la aplicación de las normas tanto del Derecho Penal, para la responsabilidad penal como al Derecho Civil, para la determinación de la responsabilidad no penal y del contenido de la reparación. Esto último significaría asimilar en derecho interno la violación de una obligación contractual con la violación de un derecho fundamental y ello, por supuesto, es improcedente. Precisamente, esta última línea de argumentación es la que intenta esgrimir el fallo del Tribunal Constitucional sobre el artículo 2331 del Código Civil, cuestión respecto de la cual nosotros discrepamos.

En efecto, incluso en el orden interno de los Estados, la responsabilidad por violaciones a los derechos humanos es distinta, se rige por patrones, principios, criterios diferentes de la responsabilidad civil regulada en el Código Civil, que solo contempla el dańo patrimonial y el daño moral, y la restitutio in integrum o la indemnización sustitutiva, en su defecto ${ }^{19}$. Tal como lo ha evidenciado la jurisprudencia de la Corte Interamericana de Derechos Humanos, la reparación en caso de violación de derechos humanos se rige por estándares distintos por la propia naturaleza de la obligación violada, aquí estamos hablando de derechos humanos que indefectiblemente tienen un componente espiritual y colectivo, el cual debe ser comprendido y considerado al momento de determinar la reparación debida $^{20}$. En muchos de estos casos de violaciones a los derechos huma-

"Si el enfoque más tradicional implica compensar por el daño físico y mental, la pérdida de oportunidades laborales y educativas y, en general, la merma o pérdida en los proyectos de vida de las víctimas, la segunda implicará el reconocimiento público de los ilícitos, la creación de una memoria histórica que permita reconstruir un estado en respeto de los derechos violentados. También considera sancionar a aquellos que hayan sido declarados responsables. De esta manera, la reparación no se agotará resarciendo por los daños materiales e inmateriales y, en estos últimos, el alcance de la reparación busca adoptar medidas de satisfacción que compensen íntegramente el daño [...] La reparación debe comprender la reivindicación de la dignidad y el buen nombre de estas personas [...]". EsPEjo, Nicolás (2008). Informe Anual sobre Derechos Humanos en Chile 2008, Santiago de Chile: Centro de Derechos Humanos, Universidad Diego Portales, pp. 482-483.

En materia de reparación: Corte Interamericana de Derechos Humanos. Sentencia de 10 de septiembre de 1993, Serie C No. 15, Caso Aloeboetoe y otros vs. Surinam. Reparaciones y Costas; Corte Interamericana de Derechos Humanos. Sentencia de 31 de agosto de 2001, Serie C No. 79, Caso de la Comunidad Mayagna (Sumo) Awas Tingni vs. Nicaragua. Fondo, Reparaciones y Costas; Corte Interamericana de Derechos Humanos. Sentencia de 22 de noviembre de 2005, Serie C No. 135, Caso Palamara Iribarne vs. Chile. Fondo, Reparaciones y Costas; Corte Interamericana de Derechos Humanos. Sentencia de 19 de septiembre 
nos, la restitutio in integrum es imposible y la simple indemnización es absolutamente insuficiente.

En esta misma línea de reflexión, debe insertarse el principio de imprescriptibilidad de la acción para hacer efectiva la responsabilidad -tanto penal como civil- del ofensor. En efecto, una vez más, por la propia naturaleza y envergadura de la obligación violada, el derecho a la reparación no puede verse frustrado por la aplicación del derecho común en materia de transcurso del tiempo, todo ello, inter alia, en virtud del propio principio de seguridad jurídica, pero, esta vez, orientado a las víctimas, a la comunidad nacional, y, en definitiva, a la humanidad. Justamente, la Asamblea General aprobó los Principios y directrices básicos sobre el derecho de las víctimas de violaciones manifiestas de las normas internacionales de derechos humanos y de violaciones graves del derecho internacional humanitario a interponer recursos y obtener reparaciones, "[c]onvencida de que, al adoptar un enfoque orientado a las víctimas, la comunidad internacional afirma su solidaridad humana con las víctimas de violaciones del derecho internacional, incluidas las violaciones de las normas internacionales de derechos humanos y del derecho internacional humanitario, así como con la humanidad en general" 21 .

Así, en el Derecho de la Responsabilidad por violaciones a los derechos humanos existen mecanismos especiales de reparación, los cuales son totalmente desconocidos por el derecho chileno, encerrado aún, en materia de reparación, en los cánones tradicionales del Derecho Civil. Por supuesto, cuando se redactó el Código Civil, con dichas normas sobre responsabilidad y reparación, era imposible que se tuviera en cuenta la reparación de violaciones a los derechos humanos. Consecuentemente, esas normas no fueron pensadas para violaciones a los derechos humanos $y$, por tanto, son insuficientes e inadecuadas.

En este contexto, una de las primeras cosas que habría que hacer es intentar una conceptualización mínima en materia de responsabilidad por violaciones a los derechos humanos. De este modo, la reparación es "restitución, indemnización, rehabilitación, satisfacción y garantías de no repetición [...] La restitución, que, en la medida de lo posible debería devolver a la víctima a la situación anterior a la violación de las normas internacionales de derechos humanos o del derecho internacional hu-

de 2006, Serie C No. 151, Caso Claude Reyes y otros vs. Chile. Fondo, Reparaciones y Costas; Corte Interamericana de Derechos Humanos. Sentencia de 28 de noviembre de 2007, Serie C No. 172, Caso del Pueblo Saramaka. vs. Surinam. Excepciones Preliminares, Fondo, Reparaciones y Costas.

21 Asamblea General Naciones Unidas. Resolución 60/147 aprobada por la Asamblea General el 16 de diciembre de 2005: Principios y directrices básicos sobre el derecho de las victimas de violaciones manifiestas de las normas internacionales de derechos humanos y de violaciones graves del derecho internacional humanitario a interponer recursos y obtener reparaciones. Preámbulo. 
manitario, comprende el restablecimiento de la libertad, los derechos, la situación social, la vida familiar y la ciudadanía de la víctima, el retorno a su lugar de residencia, la reintegración en su empleo y la devolución de sus propiedades" 22 . La Comisión Interamericana de Derechos Humanos ha considerado también que la reparación en casos de violaciones a los derechos humanos puede comprender "[...] vías administrativas, ágiles y de escaso costo, para el acceso a programas de reparaciones económicas. Esto, sin perjuicio de las demás formas de reparación no materiales, reparaciones colectivas y de los programas y servicios sociales que pudieran establecerse para la población afectada [...]"23.

Consecuentemente, en el orden de los derechos humanos, existen como mecanismos de reparación los siguientes: restitución, indemnización, rehabilitación, satisfacción y garantías de no repetición. El Derecho de los derechos humanos contempla, por tanto, tres mecanismos completamente desconocidos en el derecho común interno chileno. Por un lado, la rehabilitación, que "ha de incluir la atención médica y psicológica, así como servicios jurídicos y sociales" 24 .

Por otro lado, el Derecho de los derechos humanos ha especificado la satisfacción como mecanismo de reparación, la cual incluye, inter alia, la siguientes medidas: "a) Medidas eficaces para conseguir que no continúen las violaciones; b) La verificación de los hechos y la revelación pública y completa de la verdad, en la medida en que esa revelación no provoque más dańos o amenace la seguridad y los intereses de la víctima, de sus familiares, de los testigos o de personas que han intervenido para ayudar a la víctima o impedir que se produzcan nuevas violaciones; c) La búsqueda de las personas desaparecidas, de las identidades de los nińos secuestrados y de los cadáveres de las personas asesinadas, y la ayuda para recuperarlos, identificarlos y volver a inhumarlos según el deseo explícito o presunto de la víctima o las prácticas culturales de su familia y comunidad; d) Una declaración oficial o decisión judicial que restablezca la dignidad, la reputación y los derechos de la víctima y de las personas estrechamente vinculadas a ella; e) Una disculpa pública que incluya el reconocimiento

Espejo, Nicolás (2008) 481; Comisión de Derechos Humanos (2000). El derecho de restitución, indemnización y rehabilitación de las victimas de violaciones graves de los derechos humanos y las libertades fundamentales. Informe final del Relator Especial, Sr. M. CHerif Bassiouni, presentado en virtud de la Resolución 1999/33 de la Comisión. Doc. N.U. E/ CN.4/2000/62, de fecha 18 de enero, Anexo, pars. 21-22. una politica integral de reparaciones. Doc. OEA/Ser/L/V/II.131 Doc. 1, de fecha 19 de febrero, par. 3 .

Asamblea General Naciones Unidas (2005). Principios y directrices básicos sobre el derecho de las victimas de violaciones manifiestas de las normas internacionales de derechos humanos y de violaciones graves del derecho internacional humanitario a interponer recursos y obtener reparaciones. Resolución 60/147, aprobada el 16 de diciembre, par. IX. 21. 
de los hechos y la aceptación de responsabilidades; f) La aplicación de sanciones judiciales o administrativas a los responsables de las violaciones; g) Conmemoraciones y homenajes a las víctimas; h) La inclusión de una exposición precisa de las violaciones ocurridas en la enseńanza de las normas internacionales de derechos humanos y del derecho internacional humanitario, así como en el material didáctico a todos los niveles" 25.

Dentro de las medidas de reparación se considera, en materia de violaciones a los derechos humanos, la modificación o derogación de normas internas ${ }^{26}$.

Finalmente, los principios y estándares de los derechos humanos han establecido las garantías de no repetición como mecanismo de reparación de una violación a dichos derechos. Estas garantías de no repetición pueden comprender las siguientes: "a) El ejercicio de un control efectivo por las autoridades civiles sobre las fuerzas armadas y de seguridad; b) La garantía de que todos los procedimientos civiles y militares se ajustan a las normas internacionales relativas a las garantías procesales, la equidad y la imparcialidad; c) El fortalecimiento de la independencia del Poder Judicial; d) La protección de los profesionales del derecho, la salud y la asistencia sanitaria, la información y otros sectores conexos, así como de los defensores de los derechos humanos; e) La educación, de modo prioritario y permanente, de todos los sectores de la sociedad respecto de los derechos humanos y del derecho internacional humanitario y la capacitación en esta materia de los funcionarios encargados de hacer cumplir la ley, así como de las fuerzas armadas y de seguridad; f) La promoción de la observancia de los códigos de conducta y de las normas éticas, en particular las normas internacionales, por los funcionarios públicos, inclusive el personal de las fuerzas de seguridad, los establecimientos penitenciarios, los medios de información, el personal de servicios médicos, psicológicos, sociales y de las fuerzas armadas, además del personal de empresas comerciales; g) La promoción de mecanismos destinados a prevenir, vigilar y resolver los conflictos sociales; h) La revisión y reforma de las leyes que contribuyan a las violaciones manifiestas de las normas internacionales de derechos humanos y a las violaciones graves del derecho humanitario o las permitan" 27 .

Con frecuencia órganos internacionales piden la modificación o revocación de leyes. CoмITÉ De Derechos Humanos. Decisión de 23 de julio de 1980, Torres Ramirez v. Uruguay, par. 19, A/35/40, p. 128; Comité de Derechos Humanos. Decisión de 3 de abril de 1980, Lanza v. Uruguay, A/35/40, par. 17, p. 121; Comité de Derechos Humanos. Decisión de 21 de octubre de 1982, Dermis Barbato v. Uruguay, A/38/40, par. 11, p. 136. Asamblea General Naciones Unidas (2001). Documentos Óficiales. $56^{\circ}$ período de sesiones. Suplemento $\mathrm{N}^{\circ} 10(\mathrm{~A} / 56 / 10)$. Informe de la Comisión de derecho Internacional. $53^{\mathrm{cr}}$ período de sesiones (23 de abril a 1 de junio y 2 de julio a 10 de agosto de 2001), Nueva York, p. 234. 
¿Por qué hablar del régimen de responsabilidad que el Derecho de los derechos humanos ha elaborado a partir del Derecho Internacional? Porque en virtud del principio de la unidad del ordenamiento jurídico de los derechos humanos, este conjunto de principios y normas se encuentran sometidas a un único y mismo régimen. Por tanto, hoy en día no es posible sostener que exista una determinada normativa y determinados principios que regulan y rigen los derechos fundamentales en el orden interno (particularmente constitucional) de los Estados y, paralelamente, que existen otros principios y normas que rigen los derechos fundamentales, pero en el ámbito del Derecho Internacional, ya que ello introduce una distorsión y un principio de fragmentación que conduce a la incoherencia y a la falta de lógica sistémica en los derechos fundamentales. Por lo demás, desde un punto de vista práctico, los Estados sometidos a un sistema de protección internacional de los derechos humanos que admita la presentación de denuncias o peticiones individuales -como es el caso de Chile ante la Comisión Interamericana de Derechos Humanos y, en su caso, ante la Corte Interamericana de Derechos Humanos- quedan sujetos a un parámetro de control de su actuación interna determinado por el Derecho Internacional, en particular, por la Declaración Americana de Derechos y Deberes del Hombre y por la Convención Americana de Derechos Humanos. En consecuencia, el estándar de la ley, de la Constitución y de la práctica administrativa, legislativa y jurisdiccional de un Estado en relación con el respeto y protección de los derechos fundamentales queda determinado por el Derecho Internacional. Si a esto último se le agrega el elemento de que el Derecho Internacional impone, como obligación convencional y consuetudinaria, la adecuación de su derecho interno a los compromisos internacionales, la consecuencia no puede ser otra que una necesaria visión unitaria del orden de los derechos humanos, como un solo cuerpo monolítico de principios y normas. No puede ser de otro modo, porque hoy en día es inadmisible que un Estado sostenga que una cosa son los derechos fundamentales en el ámbito internacional; y otra, los derechos fundamentales en el ámbito interno.

Asimismo, de acuerdo con esto, este Derecho de los derechos humanos extrae sus estándares y principios del Derecho Internacional y los proyecta al derecho interno de los Estados, que en esta materia pierde sus contornos de derecho interno y se fusiona en un solo Derecho dedicado al ser humano -el Derecho de los derechos humanos-independientemente de la ubicación geojurídica del grupo, comunidad o individuo. En este orden de cosas es que tiene sentido hablar del régimen de responsabilidad y del alcance de la obligación de reparar violaciones a los derechos humanos según el régimen desarrollado y establecido por el Derecho Internacional.

El reconocimiento y aplicación del régimen existente de responsabilidad por violaciones a los derechos humanos, en el ámbito interno de los Estados, tiene proyecciones aun no visualizadas, ya que este régimen 
no solo es aplicable a situaciones de violaciones de derechos humanos tales como la tortura, la desaparición forzada de personas o la ejecución extrajudicial, sino también a la violación del derecho a la igualdad, la prohibición de la discriminación, la libertad de expresión e información, el derecho a la vida privada y a la honra de las personas, la libertad de creencia y de religión, el derecho a la educación, a la salud, a la seguridad social, a vivir en un medio ambiente libre de contaminación, el derecho de sindicación, el derecho a conservar y desarrollar sus diferencias culturales, etc. Todos estos derechos fundamentales, amparados por el orden constitucional, gozan del régimen de responsabilidad antes descrito, en caso de vulneración de los mismos. Las consecuencias de ello restan por ser extraídas, asignándole al órgano jurisdiccional, un rol importantísimo en el cumplimiento de esta tarea.

\section{3) LA REITERACIÓN DEL PRINCIPIO DE SUJECIÓN DE TODAS LAS RE- GLAS Y NORMAS DEL ORDENAMIENTO A LOS PRINCIPIOS Y VALORES CONSTITUCIONALES}

Los derechos fundamentales forman parte natural del parámetro de constitucionalidad respecto del cual se mide y contrasta la constitucionalidad de las normas, en el orden jurídico interno chileno. En efecto, forma parte de la jurisprudencia constante del Tribunal Constitucional la afirmación de que la constitucionalidad de las normas infraconstitucionales se evalúa contrastando dichas normas con los valores, principios y normas de la Constitución ${ }^{28}$. Esta afirmación no hace sino ampliar el parámetro de constitucionalidad, sin reducirla a la mera norma constitucional escrita. Por la vía de los derechos fundamentales, considerados como valor constitucional, debe incorporarse toda la amplia gama de estándares, principios y normas provenientes del Derecho Internacional de los derechos humanos. Esta incorporación permitirá al Tribunal Constitucional llenar de contenido estos valores constitucionales de una manera concordante con los estándares compartidos por la comunidad internacional, y, de esa manera, satisfacer eficientemente, sin desconexión con el sistema integral de derechos humanos, su rol de garante de la Constitución, que

\footnotetext{
"Que, como es sabido, la responsabilidad civil como deber de indemnizar el dańo inferido a otro es también procedente tratándose de la lesión de un derecho constitucional. Ello no es sino la aplicación de las bases fundamentales de nuestro ordenamiento constitucional, configurada por ciertos principios y valores básicos, entre otros, el reconocimiento de la dignidad intrínseca de la persona humana; la servicialidad del Estado, cuya finalidad propia es promover el bien común y dar seguridad y protección a la población con pleno respeto a los derechos de las personas; el respeto y promoción de los derechos esenciales del hombre, que son superiores y anteriores al Estado y a la Constitución, que no los crea sino que reconoce y asegura". TC. Rol No 943-2008, considerando $16^{\circ}$, p. 16.
} 
de alguna manera - por responder al propio concepto de Constitución- se traduce en una labor fundamental de garantía de los referidos derechos fundamentales ${ }^{29}$.

Además, el propio Tribunal Constitucional manifiesta expresamente que los derechos humanos son valores básicos del orden constitucional que irradian a todo el ordenamiento la supremacía de la dignidad humana, por lo tanto, les asigna una jerarquía que limita la propia soberanía del Esta$\mathrm{do}^{30}$. Junto con esto, y aun más importante, los derechos humanos son valores éticos universales que se incorporan en la Constitución y que se configura a través de principios y "normas rectoras y vitales que coadyuvan a desentrañar el verdadero sentido y espíritu del resto de las disposiciones de la Constitución" ${ }^{\prime 1}$. Y en este sentido, el Tribunal Constitucional sienta una regla de interpretación elemental cuando señala que "debe desecharse

29 "Que este criterio de interpretación no solo es el único que resulta conciliable con la opción por la dignidad y los derechos fundamentales de las personas adoptada por nuestra Constitución, sino que con el concepto mismo de Constitución pues, como ya lo seńalaba, en su artículo 16, la Declaración de los Derechos del Hombre y del Ciudadano, adoptada por la Asamblea Nacional Constituyente de Francia el 26 de agosto de 1789: "Toda sociedad en la cual la garantía de los derechos no está asegurada [ni determinada la separación de los poderes], carece de constitución". TC. Rol No 943-2008, considerando 330, p. 30.

30 "Que, como ya se ha seńalado, el contenido del artículo 19 de la Carta Fundamental, conjuntamente con sus artículos $1^{\circ}, 4^{\circ}$ y $5^{\circ}$, inciso segundo, de la misma, configuran principios y valores básicos de fuerza obligatoria que impregnan toda la Constitución de una finalidad humanista que se irradia en la primacía que asignan sus disposiciones a la persona humana, a su dignidad y libertad natural, en el respeto, promoción y protección a los derechos esenciales que emanan de la naturaleza humana, que se imponen como limitación del ejercicio de la soberanía y como deber de los órganos del Estado". TC. Rol No 943-2008, considerando $30^{\circ}$, p. 19; La Corte Suprema, en el caso por el secuestro calificado de Troncoso Muñoz y otros, ha señalado claramente, respecto del valor y rango jerárquico de los tratados de derechos humanos y de los derechos fundamentales mismos, que "el inciso segundo del artículo $5^{\circ}$ de la Constitución Política de la República, preceptúa que el ejercicio de la soberanía aparece limitado por "los derechos esenciales de la persona humana" siendo "deber de los órganos del Estado respetar y promover tales derechos garantizados por esta Constitución así como por los tratados internacionales ratificados por Chile que se encuentren vigentes". Valores que son superiores a toda norma que puedan disponer las autoridades del Estado, incluido el propio Poder Constituyente derivado, lo que impide que sean desconocidos (Fallos del Mes $\mathrm{N}^{\circ}$ 446, sección criminal, página 2.066), aun en virtud de consideraciones de oportunidad en la política social o de razones perentorias de Estado para traspasar esos límites. Otorgándole rango constitucional a los tratados que garantizan el respeto de los derechos humanos, concediéndoles una jerarquía mayor que a los demás tratados internacionales, en cuanto regulan los derechos esenciales que emanan de la naturaleza humana”. Corte Suprema. 10 de mayo de 2007, Rol No 3452-2006, Caso sobre el secuestro calificado de Troncoso Muñoz, Ricardo Aurelio y otros, considerando $66^{\circ}$.

31 "Que estos principios y valores, como ya se recordó -y lo hace manifiesto el inciso segundo del artículo $6^{\circ}$ de la Constitución, que precisa que sus preceptos obligan no solo a los titulares o integrantes de los órganos del Estado sino a toda persona, institución o grupo- no configuran meras declaraciones programáticas sino que constituyen mandatos expresos para gobernantes y gobernados, debiendo presidir la labor del intérprete constitucional, en cuanto normas rectoras y vitales que coadyuvan a desentrañar el verdadero sentido y espíritu del resto de las disposiciones de la Constitución”. TC. Rol No 943-2008, considerando 31º, p. 29. 
toda interpretación de las normas constitucionales que resulte contradictoria con los aludidos principios y valores rectores de la Carta Suprema"32.

Por eso es que resulta trascendental determinar los valores y principios rectores de la Carta Fundamental, todos los cuales configuran el verdadero espíritu de la Constitución que se debe preservar. En este sentido, en la sentencia sobre el artículo 2331 del Código Civil, el Tribunal Constitucional claramente afirmó que entre los principios y valores básicos del ordenamiento constitucional chileno se encuentran "(a) el reconocimiento de la dignidad intrínseca de la persona humana; (b) la servicialidad del Estado, cuya finalidad propia es promover el bien común y dar seguridad y protección a la población con pleno respeto a los derechos de las personas; (c) el respeto y promoción de los derechos esenciales del hombre, que son superiores y anteriores al Estado y a la Constitución, que no los crea sino que reconoce y asegura" 33 . Luego, los jueces constitucionales continuaron para reafirmar que los anteriores son principios y normas rectoras y vitales del orden constitucional y que estos principios y valores constituyen el espíritu de la Constitución.

Además, el propio órgano jurisdiccional constitucional confirma el principio de la absoluta vinculatoriedad de los valores y principios constitucionales, los cuales pasan a componer el parámetro principal de verificación de la constitucionalidad. En efecto, la sentencia sobre el artículo 2331 del Código Civil señala que estos principios y valores "no configuran meras declaraciones programáticas sino que constituyen mandatos expresos para gobernantes y gobernados, debiendo presidir la labor del intérprete constitucional, en cuanto normas rectoras y vitales que coadyuvan a desentrañar el verdadero sentido y espíritu del resto de las disposiciones de la Constitución" 34 .

Finalmente, el Tribunal Constitucional, en la sentencia del artículo 2331 del Código Civil nos aporta una respuesta a la pregunta de por qué es importante hablar de los valores constitucionales, cuando afirma que "debe desecharse toda interpretación de las normas constitucionales que resulte contradictoria con los aludidos principios y valores rectores de la Carta Suprema" 35 , que reiteramos, según nuestra visión, están compuestos por la democracia, el estado de derecho y los derechos humanos.

"Que, por lo recién expresado, debe desecharse toda interpretación de las normas constitucionales que resulte contradictoria con los aludidos principios y valores rectores de la Carta Suprema. Ello lleva a concluir que, frente a las interpretaciones posibles del alcance de la protección constitucional de un derecho fundamental, deba desecharse la que admita que el legislador pudo regular sus efectos hasta extremos que, en la práctica, imposibilitan la plenitud de su vigencia o comprimen su contenido a términos inconciliables con su fisonomía".

TC. Rol No 943-2008, considerando $32^{\circ}$, p. 29.

33 TC. Rol No 943-2008, considerando $16^{\circ}$, p. 17.

34 TC. Rol No 943-2008, considerando $31^{\circ}$, p. 29.

35 TC. Rol No $943-2008$, considerando $32^{\circ}$, p. 29. 


\section{4) La CONSTitución de la CONSTITUCIÓN: El PRINCIPIO DE SU- PREMACÍA DE LOS DERECHOS FUNDAMENTALES}

Uno de los avances más notables en el derecho constitucional contemporáneo ha sido la continua consolidación ascendente de la dignidad humana y de los derechos fundamentales como el sustratum mismo de esta rama del Derecho y en realidad de todo el ordenamiento jurídico. Desde el punto de vista de las obligaciones que se generan, el respeto, la promoción, la garantía y la protección efectiva de estos derechos fundamentales, cualesquiera que estos sean-civiles, políticos, económicos, sociales y culturales- configuran un derecho objetivo que es consubstancial al estado de derecho y a un régimen materialmente democrático. Estos tres elementos -democracia, estado de derecho y derechos fundamentales- constituyen las bases esenciales de un estado constitucional contemporáneo. Todos estos componentes, entienden al Estado como una organización jurídico política que se justifica en razón del bienestar del ser humano, ya sea en su manifestación individual o colectiva, de manera de alcanzar la mayor autorrealización material y espiritual del individuo, del grupo o del pueblo.

Todo lo anterior constituye, en términos generales, los principales valores y el espíritu de la Constitución, sobre todo, bajo una visión, como la Constitución chilena, fundamentalmente humanista. En este sentido, el derecho creado, ya sea su origen estatal o interestatal, se encuentra subordinado a un ordenamiento jurídico objetivo, constituido por el orden de los derechos humanos comprendidos en términos de derechos, esto es, en términos de libertades, de facultades o poderes de determinación de la acción o abstención. Así, los derechos fundamentales, tanto en el orden estatal como interestatal, como en cualquier estructura y organización social, configurarían la bóveda o cúspide del edificio jurídico, en fin, su piedra angular. En otras palabras y utilizando la expresión de Philip Allott, los derechos humanos constituirían la Constitución de la Constitución ${ }^{36}$.

Esto es, a nuestro entender, lo que el Tribunal Constitucional chileno denomina el espíritu constitucional o el espíritu de la Constitución ${ }^{37}$. En esta línea de reflexión, la sentencia pronunciada por el Tribunal Constitucional en el caso del artículo 2331 del Código Civil, abre una nueva etapa en la dinámica evolución de los derechos humanos en el ordenamiento jurídico interno chileno, en lo que dice relación con la jerarquía normativa de los derechos fundamentales en el orden jurídico. University Press, p. 170.

37 TC. Rol No $943-2008$, considerando $16^{\circ}$, p. 17.
} 
En el derecho interno chileno ha habido una vertiginosa evolución en esta materia. En esta evolución, se puede apreciar claramente el camino recorrido tanto por la justicia ordinaria como por la justicia constitucional, el cual no ha sido siempre convergente. Además, se puede observar una forma de abordar este tema en aquellos casos que se refieren a violaciones a los derechos fundamentales ocurridos en la época del gobierno militar y otros ocurridos bajo régimen democrático. A continuación, efectuaremos, solo con un fin comparador y relacional, un breve examen de la trayectoria recorrida a través de sus pronunciamientos tanto por la justicia ordinaria y, luego, por la justicia constitucional.

\section{(4.1) JUSTICIA ORDINARIA}

En primer lugar, desde la perspectiva de la justicia ordinaria y en el ámbito de las violaciones a los derechos fundamentales ocurridas durante el gobierno militar, la Corte Suprema ha reconocido y reiterado en diversas ocasiones el principio de supremacía de los derechos esenciales que emanan de la naturaleza humana. En efecto, este Tribunal ha señalado que estos derechos esenciales tienen aplicación preeminente y que dichos derechos constituyen un límite a la soberanía y son superiores a toda norma que puedan disponer las autoridades del Estado. Así, ya en el año 1996, la Corte Suprema, en el caso del asesinato de Lumi Videla Moya, reconoció expresamente que los derechos esenciales que emanan de la naturaleza humana son un límite a la soberanía interna del Estado, todo ello, en un caso por violaciones a los derechos fundamentales ocurridas durante el gobierno militar en Chile, y esta vez, la declaración se efectuó en una sentencia que beneficiaba a los imputados. En efecto, la Corte Suprema afirmó que "de la historia fidedigna del establecimiento de la norma constitucional contenida en el artículo $5^{\circ}$ de la Carta Fundamental queda claramente establecido que la soberanía interna del Estado de Chile reconoce su límite en los derechos que emanan de la naturaleza humana, valores que son superiores a toda norma que puedan disponer las autoridades del Estado, incluido el propio poder Constituyente, lo que impide sean desconocidos" 38 .

Con posterioridad, la Corte Suprema ha reiterado varias veces esta afirmación. Algunos de estos casos están relacionados con violaciones a los derechos fundamentales ocurridas durante el gobierno militar. Esta vez, las declaraciones se han producido en argumentaciones en beneficio de las víctimas. Así, en el caso de la desaparición de Pedro Poblete Córdova, la Corte Suprema afirmó que "en cuanto el Pacto (Pacto Internacional de

38 Corte Suprema. 30 de enero de 1996, Rol No 5.476-94, Caso cl Osvaldo Romo Mena (asesinato de Lumi Videla Moya). Queja Criminal, considerando $4^{\circ}$. 
Derechos Civiles y Políticos) persigue garantizar los derechos esenciales que emanan de la naturaleza humana, tiene aplicación preeminente, puesto que esta Corte Suprema, en reiteradas sentencias ha reconocido que de la historia fidedigna del establecimiento de la norma constitucional contenida en el artículo $5^{\circ}$ de la Carta Fundamental queda claramente establecido que la soberanía interna del Estado de Chile reconoce su límite en los derechos que emanan de la naturaleza humana; valores que son superiores a toda norma que puedan disponer las autoridades del Estado, incluido el propio Poder Constituyente, lo que impide sean desconocidos" 39 . En este mismo caso, resulta muy interesante la aseveración que, acto seguido, efectúa la misma Corte Suprema, al señalar que "en tales circunstancias omitir aplicar dichas disposiciones importa un error de derecho que debe ser corregido por la vía de este recurso, en especial si se tiene presente que de acuerdo a los principios del Derecho Internacional los Tratados Internacionales deben interpretarse y cumplirse de buena fe por los Estados; de lo que se colige que el Derecho Interno debe adecuarse a ellos y el legislador conciliar las nuevas normas que dicte a dichos instrumentos internacionales, evitando transgredir sus principios, sin la previa denuncia de los Convenios respectivos" 40 . Esta afirmación nos permite señalar que la Corte Suprema le asigna el valor de norma preeminente, e incluso la misma jerarquía de los derechos esenciales, a los instrumentos internacionales de derechos humanos ratificados por Chile, todo ello, en concordancia con el artículo $5^{\circ}$ inciso $2^{\circ}$ de la Constitución chilena ${ }^{41}$. Una afirmación que continúa y reitera la jurisprudencia sentada en el caso del asesinato de Lumi Videla Moya, es la aseveración, de idéntico tenor, que la Corte Suprema realiza en el ańo 2006 en el caso de Paulino Flores Rivas y otros (denominado caso Molco) ${ }^{42}$.

Este principio, sostenido en el caso Lumi Videla, de supremacía de los derechos humanos en el orden jurídico, fue completado y complementado por la Corte Suprema en el caso del homicidio calificado de Victor Pinto Pérez (denominado caso Chena), en donde dicha Corte le asigna expresamente al artículo $5^{\circ}$ de la Constitución chilena, el significado normativo

Corte Suprema. 9 de septiembre de 1998, Rol o 469-1998, Detención ilegal de Pedro Poblete Córdova. Recurso de Casación en el Fondo Acogido, considerando $10^{\circ}$. CS. Rol No 469-1998, considerando $10^{\circ}$.

$41 \quad$ "20. Que, en concepto del recurrente, el error que atribuye a los jueces se produjo de la siguiente manera: (...) e) al no aplicar tratados internacionales sobre la materia, en especial el artículo 15 No 2 del Pacto Internacional de Derechos Civiles y Políticos, por los que el Estado chileno adquirió un compromiso de investigar y sancionar los ilícitos constitutivos de atentados graves contra las personas o crímenes de lesa humanidad, textos que tienen primacía constitucional según el inciso segundo del artículo $5^{\circ}$ de la Constitución Política de la República y se imponen por sobre la legislación interna que se les oponga, como sería el caso de la ley de amnistía en objeción". CS. Rol No 469-1998, considerando $2^{\circ}$. secuestro calificado y homicidio, considerando $22^{\circ}$. 
de atribuirle rango constitucional a los tratados internacionales de derechos humanos. En efecto, en dicho fallo, la Corte Suprema afirmó que "el inciso segundo del artículo $5^{\circ}$ de la Constitución Política de la República, preceptúa que el ejercicio de la soberanía se encuentra limitado por "los derechos esenciales de la persona humana" siendo "deber de los órganos del Estado respetar y promover tales derechos garantizados por esta Constitución así como por los tratados internacionales ratificados por Chile que se encuentren vigentes". Valores que son superiores a toda norma que puedan disponer las autoridades del Estado, incluido el propio Poder Constituyente derivado, lo que impide que sean desconocidos, aun en virtud de consideraciones de oportunidad en la política social o de razones perentorias de Estado para traspasar esos límites. Otorgándole rango constitucional a los tratados que garantizan el respeto de los derechos humanos, concediéndoles una jerarquía mayor que a los demás tratados internacionales, en cuanto regulan los derechos esenciales que emanan de la naturaleza humana. En definitiva los derechos humanos asegurados en un tratado se incorporan al ordenamiento jurídico interno, formando parte de la Constitución material adquiriendo plena vigencia, validez y eficacia jurídica, no pudiendo ningún órgano del Estado desconocerlos y debiendo todos ellos respetarlos y promoverlos, como asimismo, protegerlos a través del conjunto de garantías constitucionales destinadas a asegurar el pleno respeto de los derechos. Esta obligación no solo deriva del mentado artículo $5^{\circ}$, sino también del $1^{\circ}$, incisos primero y cuarto, y $19, \mathrm{~N}^{\circ} 26^{\circ}$, de la Carta Magna y de los mismos tratados internacionales, entre éstos del artículo $1^{\circ}$ común a los Cuatro Convenios de Ginebra, que establece el deber de los Estados Partes de respetar y hacer respetar el derecho internacional humanitario" 43 .

Más adelante, la Corte Suprema continúa para agregar una remarcable declaración en cuanto a la actitud que debe guiar al intérprete en casos como el de marras. Así, la Corte señaló que "lo que hasta ahora se ha venido exponiendo es el resultado obligado de la interpretación de la ley y de los dictados de la razón que ha debido ser adoptada conforme a una valoración axiológica de la justicia que impone el deber de preferir el sentido en que las normas jurídicas tengan efecto sobre aquel en que se les niegue eficacia" ${ }^{44}$. En otras palabras, la Corte Suprema afirma en esta sentencia la plena vigencia del principio de interpretación en derechos humanos denominado principio del efecto útil (principe de l'effet utile).

Una afirmación similar sobre el principio de supremacía de los derechos humanos en el orden jurídico ha sido efectuada por la Cor-

\footnotetext{
43 Corte Suprema. 13 de marzo de 2007, Rol 3125-04, Caso Pinto Pérez, Victor Raúl, Homicidio calificado (Caso Chena). Recurso de casación en el fondo, considerando 39\%.

44 CS. Rol 3125-04, considerando $40^{\circ}$.
} 
te Suprema en otro caso de violaciones a los derechos fundamentales en el gobierno militar. En efecto, en el caso de secuestro calificado de Guillermo Gómez Aguilar, la Corte Suprema señaló claramente que "también los principios internacionales referidos, los convenios, pactos y tratados en que se reconocen los derechos humanos y las garantías a nivel de tribunales nacionales, gozan de primacía constitucional, cuyo colofón -de acuerdo a una interpretación progresiva y finalista de la Constitución- es que prevalecen sobre la legislación interna, puesto que se entiende que la prefieren, perfeccionan y complementan. Siendo, por lo mismo, tal normativa puede ser invocada por todos los individuos, atendido el compromiso moral y jurídico del Estado ante la comunidad internacional de respetarlos, promoverlos y garantizarlos" ${ }^{35}$. Este caso es coincidente en parte y ligeramente diferente de los anteriores. Por un lado, este caso es coincidente porque reitera la afirmación de la primacía constitucional de los derechos fundamentales. Por otro, este caso es ligeramente diferente de los anteriores por cuanto alude a las fuentes de los derechos, al referirse a "los principios internacionales, los convenios, pactos y tratados". Desafortunadamente, en esta afirmación, creemos que más bien por descuido que por intención, se omitió la referencia a la fuente de Derecho Internacional más relevante, esto es, la norma consuetudinaria.

Esta última idea ha sido ratificada por la Corte de Apelaciones de Puerto Montt en el caso Arroyo Thoms, Tamara y otras con Director de Liceo de Niñas, en donde dicha Corte afirmó que la Convención sobre los Derechos del Niño de 1989 -un tratado internacional de derechos humanos- tiene idéntico valor a los derechos esenciales que emanan de la naturaleza humana y, por tanto, rango constitucional. En efecto, en dicho caso, la Corte de Apelaciones aseveró que "lo informado por la autoridad de Educación, es plenamente concordante con los principios normativos y doctrinarios vigentes en nuestro Ordenamiento Jurídico, conforme a los cuales la potestad disciplinaria de los diversos entes, que ha sido estimada como un verdadero derecho penal de carácter administrativo, debe ejercerse con sujeción a las normas de un debido proceso, con pleno resguardo de los derechos esenciales que emanan de la naturaleza humana, en este caso doblemente resguardados respecto a las recurrentes, tanto por las normas pertinentes del artículo 19 de nuestra Constitución Política, como de la Convención sobre los Derechos del Nińo, que en virtud del artículo $5^{\circ}$ de la misma Carta Fundamental, tienen idéntico valor, constituyéndose en limitaciones al ejercicio de la soberanía del Estado, y por ende a la potestad sancionatoria de sus or- 
ganismos y de los grupos intermedios a través de los cuales se organiza y estructura la sociedad" 46 .

\section{(4.2) JUSTICIA CONSTITUCIONAL}

En segundo lugar, desde la perspectiva de la justicia constitucional, por su parte, el Tribunal Constitucional ha seguido una trayectoria ascendente en el proceso de reconocimiento del principio de supremacía de los derechos fundamentales en el orden jurídico. En efecto, en un primer momento, en el caso Clodomiro Almeyda, el Tribunal Constitucional ya había efectuado una afirmación en torno a la supremacía de los derechos fundamentales en el orden jurídico, que, a nuestro modo de ver, no había sido madurada con efectos concretos y reales, hasta ahora, con la sentencia del caso del artículo 2331 del Código Civil. En el caso de Clodomiro Almeyda, el Tribunal seńaló como principios y valores fundamentales de la comunidad chilena, la superioridad de los derechos fundamentales, al afirmar que "el ordenamiento institucional estructurado por la Constitución de 1980 descansa sobre ciertos principios y valores básicos, entre los cuales, cabe señalar, por su íntima vinculación con el problema que se analiza, los siguientes: la libertad del hombre, que los derechos fundamentales de la persona humana son anteriores y superiores al Estado y a la Constitución, razón por la cual esta no los crea sino que los "reconoce y asegura"; que el Estado en cumplimiento de su finalidad propia, cual es promover el bien común, debe darles segura y eficaz protección debiendo destacarse, en la especie, "la seguridad y certeza jurídica"; que el ejercicio de la soberanía que se realiza por el pueblo y por las autoridades que la Constitución establece reconoce como limitación el respeto a los derechos esenciales que emanan de la naturaleza humana [... ${ }^{347}$. En este remarcable fallo, el Tribunal Constitucional reafirmó, además, el principio de ejecutividad de las disposiciones, principios y valores constitucionales, al señalar que "estos preceptos no son meramente declarativos sino que constituyen disposiciones expresas que obligan a gobernantes y gobernados tanto en sí mismas, como también, en cuanto normas rectoras y vitales que coadyuvan a desentrańar el verdadero sentido y espíritu del resto de las disposiciones de la Constitución" 48 .

\footnotetext{
46 Corte de Apelaciones de Puerto Montt. 3 de enero de 2001, Rol No 2840-2001, Arroyo Thoms, Tamara y otras con Director de Liceo de Niñas. Recurso de protección, considerando 5º. 47 Tribunal Constitucional de Chile. 21 de diciembre de 1987, Rol 46- 1987, Requerimiento formulado por el ministro del interior, en virtud del artículo 82 de la Constitución, para que se declare la responsabilidad del señor Clodomiro Almeyda Medina por infracción al artículo $8^{\circ}$ de la Constitución, considerando $19^{\circ}$, p. 27.

TC. Rol 46- 1987 , considerando $21^{\circ}$, p. 28.
} 
Una de las virtudes de esta afirmación y reconocimiento del principio de supremacía de los derechos fundamentales, contenida en el fallo pronunciado en el caso de Clodomiro Almeyda, es que el Tribunal Constitucional la efectuó en 1987, es decir, con anterioridad a la reforma constitucional de 1989 , en virtud de la cual se incorporó el inciso $2^{\circ}$ del actual artículo $5^{\circ}$ de la Constitución Política de Chile. En consecuencia, esta primacía supraconstitucional alcanza hoy no solo al contenido normativo -los derechos- sino también al continente de los mismos, esto es, a sus fuentes de producción, por tanto, deben entenderse comprendidos en esta supremacía las normas convencionales, las normas consuetudinarias y los principios generales, incluyendo, por supuesto, la fuente última de todos los derechos, que el profesor Cançado Trindade denomina la conciencia jurídica universal. Uno de los ejemplos de la conciencia jurídica universal como fuente de derechos y obligaciones es la cita que hace el Instituto de Derecho Internacional, en su Declaración de Brujas sobre el uso de la fuerza, en 2003, cuando recuerda los principios de prohibición del uso de la fuerza y los principios elementales del Derecho Internacional Humanitario, y de que la agresión y el terrorismo es un crimen internacional. Finalmente, aludiendo a la conciencia universal de la humanidad, solicita enfáticamente a todos los Estados respetar los referidos principios fundamentales ${ }^{49}$.

En este orden de cosas, algunos podrían argumentar que la Constitución solo contempla en su letra, los tratados internacionales de derecho humanos ratificados y vigentes, pero la verdad, es que esta interpretación literal civilista, esto es, conforme a la letra de la Constitución, es contraria al espíritu de la norma fundamental, y a los valores y principios que ella abraza. Por lo demás, dicha interpretación, sería ilógica e incoherente con un sistema integral e integrador de fuentes de los derechos humanos, donde se estaría privilegiando unos derechos humanos -los contenidos en los tratados internacionales- y discriminando otros -los contenidos en las normas consuetudinarias- por ejemplo. Como se verá más adelante, la sentencia del Tribunal Constitucional sobre el artículo 2.331 del Código Civil, viene a desvirtuar esta última posición y a ratificar el principio de primacía de los derechos fundamentales en base a un sistema integral de los mismos.

En el caso sobre la inconstitucionalidad del Proyecto de Ley sobre responsabilidad penal adolescente, el Tribunal Constitucional hizo una tímida referencia al artículo $5^{\circ}$ de la Constitución, más bien reiterando la obligación del Estado de respetar y promover los derechos fundamentales, cuando señaló que "lo que corresponde al Tribunal Constitucional es session. September 2. 
cerciorarse de que las penas obedezcan a fines constitucionalmente lícitos y de que no se vulneren los límites precisos que la misma Carta ha impuesto como, por ejemplo, en el caso del artículo 19 № 1 , que prohíbe la aplicación de apremios ilegítimos, del artículo 19 № 7, inciso segundo, letras g) y h), que impiden establecer la pena de confiscación de bienes o la de pérdida de los derechos previsionales, todo lo cual tiende, finalmente, a dar cumplimiento al deber que el inciso segundo del artículo $5^{\circ}$ de la Constitución impone a los órganos del Estado en orden a respetar y promover los derechos esenciales del ser humano" 50 .

En este mismo caso, el Ministro Vodanovic fue más lejos y fundó su voto disidente, reconociendo el principio de la limitación de la soberanía por los derechos esenciales que emanan de la naturaleza humana, al seńalar que "el artículo 5\%, inciso segundo, de la Carta Fundamental establece como límite al ejercicio de la soberanía el respeto por los derechos fundamentales, obligando al Estado a respetarlos y, a la vez, a promoverlos" 51 .

En cambio, en el caso Aarón Vásquez, solo aludió a una garantía constitucional genérica de limitación del poder estatal, sin manifestarse expresamente a propósito de su rango jerárquico, como sí ocurrió en el caso Clodomiro Almeyda. En efecto, en el contexto del debido proceso penal, el Tribunal Constitucional afirmó que "es menester señalar que dentro de los principios informadores del proceso penal, se encuentra la configuración del mismo en base a la única o a la doble instancia, opción de política legislativa que corresponde al legislador decidir, en el marco de las reservas legales específicas de las garantías de legalidad del proceso y del racional y justo procedimiento, contenidas en el artículo 19 número 3 de la Carta Fundamental, que deben ser entendidas, además, limitadas por la garantía genérica de respeto a los derechos fundamentales como límite al poder estatal, establecida en la primera parte del inciso segundo del artículo $5^{\circ}$ de la misma" 52 .

Recientemente, el Tribunal Constitucional ha reconocido también el principio de supremacía de los derechos fundamentales, más bien por la vía de afirmar que los derechos esenciales son una limitación al ejercicio de la soberanía, a propósito del derecho a la tutela judicial efectiva. En efecto, en el Requerimiento de inaplicabilidad deducido por Asesoría y Ser-

Tribunal Constitucional de Chile. 13 de junio de 2007, Rol № 786-2007, Requerimiento de Diputados para que se declare la inconstitucionalidad del número $3^{\circ}$ del articulo único del Proyecto de Ley modificatorio de la Ley $N^{\circ} 20.084$, que establece un sistema de responsabilidad de los adolescentes por infracciones a la ley penal, en la parte en que dicha norma modifica el artículo $23 \mathrm{~N}^{\circ} 1$ del citado cuerpo legal, considerando $30^{\circ}$.

51 TC. Rol No 786-2007, voto disidente Ministro Hernán Vodanovic Schnake, considerando $2^{\circ}$.

52 Tribunal Constitucional de Chile. 30 de enero de 2008, Rol № 986-2007, Requerimiento de inaplicabilidad presentado por Aarón David Vásquez Muñoz, respecto del artículo 387, inciso segundo, del Código Procesal Penal, en causa RUC N 0600764824-1, del $8^{\circ}$ Juzgado de Garantia de Santiago, considerando $26^{\circ}$, p. 28. 
vicio Empresarial Limitada, el Tribunal Constitucional señala que "desde hace décadas, esta Magistratura ha reconocido el derecho a acudir a la justicia, llamado también derecho a la acción o derecho a la tutela judicial, como presupuesto básico de las garantías de la igual protección en el ejercicio de los derechos y del debido proceso, contempladas en el $\mathrm{N}^{\circ} 3$ del artículo 19 de la Constitución, a la vez que como uno de los componentes esenciales de un orden jurídico construido, en una sociedad democrática, sobre la base del respeto a la libertad y dignidad del ser humano; que reconoce como limitación del ejercicio de la soberanía e impone como deber de los órganos del Estado el respeto de los derechos esenciales del hombre" 53 .

Dentro de los valores que el Tribunal Constitucional reafirma, en su sentencia sobre el artículo 2331 del Código Civil, como vitales y rectores del orden interno chileno, se encuentran la democracia, el estado de derecho y los derechos humanos, los cuales son compartidos por los Estados inspirados en el constitucionalismo contemporáneo. Así, los jueces constitucionales afirman que "el contenido del artículo 19 de la Carta Fundamental, conjuntamente con sus artículos $1^{\circ}, 4^{\circ}$ y $5^{\circ}$, inciso segundo, de la misma, configuran principios y valores básicos de fuerza obligatoria que impregnan toda la Constitución de una finalidad humanista que se irradia en la primacía que asignan sus disposiciones a la persona humana, a su dignidad y libertad natural, en el respeto, promoción y protección a los derechos esenciales que emanan de la naturaleza humana, que se imponen como limitación del ejercicio de la soberanía y como deber de los órganos del Estado" 54 . En este caso, los jueces constitucionales se refieren a la primacía de la persona humana y al hecho de que los derechos esenciales son una limitación al ejercicio de la soberanía. El órgano jurisdiccional constitucional confirma, en forma irredargüible, la supremacía de los derechos humanos -incluso por sobre la Constitución-, desde la perspectiva del derecho interno, cuando señala que "el respeto y promoción de los derechos esenciales del hombre, (sic) son superiores y anteriores al Estado y a la Constitución, que no los crea sino que reconoce y asegura" 55 .

Esta forma de abordar el ordenamiento jurídico interno -promoviendo la supremacía de los derechos humanos- tiene múltiples impactos en el logro de niveles avanzados de satisfacción y autorrealización material y espiritual de los individuos y grupos, en condiciones de dignidad, igual-

Tribunal Constitucional de Chile. 10 de julio de 2008, Rol No 968-2007, Requerimiento de inaplicabilidad deducido por Asesoria y Servicio Empresarial Limitada respecto del inciso tercero del artículo 474 del Código del Trabajo, en la causa Rol No 806-07, caratulada "ASESORIA Y SERVICIO con DIRECCIÓN DEL TRABAJO" del $5^{\circ}$ Juzgado de Letras del Trabajo de Santiago, considerando $29^{\circ}$,

54 TC. Rol No $943-2008$, considerando $30^{\circ}$, p. 29.

55 TC. Rol No 943-2008, considerando $16^{\circ}$, p. 17. 
dad y libertad, todo lo cual configura el corazón del espíritu constitucional del siglo XXI.

\section{5) VALORACIÓN}

1) La sentencia del Tribunal Constitucional sobre el artículo 2331 del Código Civil es remarcable por diversos motivos. En primer lugar, reconoce la existencia del principio de responsabilidad por violaciones a los derechos humanos como incorporado en la Constitución y en todo nuestro ordenamiento. En segundo lugar, refuerza la idea de los valores, principios y del espíritu de la Constitución parámetro material de la labor de constitucionalidad de los jueces constitucionales. Finalmente, en tercer lugar, reafirma el principio constitucional rector y vital consistente en la supremacía -incluso superior a la propia Constitución- de los derechos fundamentales.

2) Una observación crítica que nos merece esta sentencia dice relación con el principio de responsabilidad en casos de violaciones a los derechos fundamentales, en el sentido de rechazar por inadecuado la aplicación del régimen de responsabilidad civil que establece el Código Civil para estos casos de reparación por violaciones a los derechos fundamentales. En efecto, según nuestro entender, la responsabilidad por violación de los derechos fundamentales tiene un régimen estructurado, elaborado y adecuado, para dar respuesta al principio de reparación integral en casos de violaciones a los derechos humanos. Este régimen de responsabilidad en casos de violaciones a los derechos humanos tiene su origen en el Derecho Internacional de los derechos humanos y permite a la jurisdicción proporcionar una reparación adecuada, íntegra y eficaz para reparar el dańo producido al individuo, al grupo o a la comunidad -dependiendo de la naturaleza individual o colectiva del derecho fundamental violado-. Tal como se puede apreciar de la práctica de la Corte Suprema, este régimen especial y diferenciado de responsabilidad por violación de los derechos fundamentales resulta mucho más adecuado para satisfacer plenamente el derecho a la reparación que tienen las víctimas de violaciones a los derechos humanos, atendida la naturaleza del derecho humano y los efectos que, la violación a un derecho humano en sí mismo considerado, produce.

3) Por otra parte, uno de los puntos más altos que alcanza esta sentencia del Tribunal Constitucional, y que debe ser en todo los casos destacado, es el reconocimiento y reafirmación del principio constitucional de supremacía de los derechos humanos. En efecto, en su pronunciamiento, los jueces constitucionales han afirmado una vez más y con justa razón que los derechos fundamentales son superiores a la misma Constitución. Este es un principio inherente al constitucionalismo contemporáneo 
y responde a la idea de una Constitución-valor o una Constituciónprincipio, donde los principios y valores constitucionales debe ser la guía principalísima del órgano jurisdiccional constitucional al momento de efectuar su control de juridicidad constitucional y cuyo fin último debiera ser preservar en forma preeminente el espíritu constitucional. A nuestro entender, el espíritu constitucional reside esencialmente en la democracia, el estado de derecho y los derechos humanos.

Esta forma de enfrentar la jurisdicción constitucional y de abordar el ordenamiento jurídico interno tiene múltiples impactos en el logro de niveles avanzados de satisfacción y autorrealización material y espiritual de los individuos y grupos, en condiciones de dignidad, igualdad y libertad. Una de las consecuencias en las formas de abordar el orden jurídico interno implica que no tiene sentido efectuar la distinción entre fuente de producción del derecho y el derecho mismo, en el sentido de la jerarquía normativa. En términos de derechos humanos, no tiene sentido efectuar la distinción entre tratados internacionales de derecho humanos o derechos humanos o esenciales del hombre ya que al afirmar la superioridad del derecho humano, ello acarrea como consecuencia lógica, sostener la superioridad -incluso por sobre la Constitución- del instrumento que lo contiene. Como se ha dicho, este principio y no otro explica por qué Chile ha debido modificar o adecuar su Constitución en dos ocasiones, como consecuencia de su incompatibilidad o falta de adecuación con la Convención Americana de Derechos Humanos. 